\title{
МЕТОДОЛОГІЧНІ ПІДХОДИ ДО ВИЗНАЧЕННЯ ПОГЛИНУТОЇ ДОЗИ АЕРОЗОЛЮ ОКРЕМИМИ ДІЛЯНКАМИ ОРГАНІВ ДИХАННЯ
}

\author{
М. О. Кашуба, О. Є. Федорів \\ ДВНЗ «Тернопільський державний медичний університет імені І. Я. Горбачевського» \\ Запропоновано нові методологічні підходи до визначення поглинутоїдози аерозолю окремими ділянками органів \\ дихання. В основу запропонованого рішення покладено розробку приладу з автоматичною системою управління, \\ що дозволяє визначати сорбційну здатність окремих ділянок органів дихання. \\ Ключові слова: аерозоль, дисперсність, органи дихання.

\section{МЕТОДОЛОГИЧЕСКИЕ ПОДХОДЫ К ОПРЕДЕЛЕНИЮ ПОГЛОЩЕННОЙ ДОЗЫ АЭРОЗОЛЯ ОТДЕЛЬНЫМИ УЧАСТКАМИ ОРГАНОВ ДЫХАНИЯ} \\ Н. А. Кашуба, О. Е. Федорив \\ ГВУЗ \\ $\begin{array}{cc}\text { «Тернопольский } & \text { государственный медицинский } \\ \text { имени } & \text { И.Я.Горбачевского» }\end{array}$
}

\begin{abstract}
Предложены новые методологические подходы к определению поглощенной дозы аэрозоля отдельными участками органов дыхания. В основну предложенного решения возложено разработку прибора с автоматической системой управления, позволяющего определять сорбционную способность определенных участков органов дыхания.
\end{abstract}

Ключевые слова: аэрозоль, дисперсность, органы дыхания.

\section{METHODOLOGICAL APPROACHES TO THE DETERMINATION OF AB SORBED AEROZOL DOSE BY SEPARATE ZONES OF RESPIRATORY ORGANS}

\author{
M. O. Kashuba, O. Ye. Fedoriv \\ TегnорідState Medical University by I. Ya. Horbachevsky
}

\begin{abstract}
New methodological approaches of determination of absorbed aerosol dose by some zone of respiratory tract were proposed. On the basis of the proposed solution is automatic control system that allows to deter mine the sorption capacity of some areas of respiratory organs.
\end{abstract}

Key words: aerosol, dispersion, respiratory organs

Вступ. Існує ряд інфекційних захворювань, що виникають внаслідок потрапляння пилу в органи дихання людини, і насамперед, пилу рослинного та тваринного походження (деревний, бавовняний, лляний, вовняний та ін.) Такий пил може містити гриби, патогенні та непатогенні бактерії (M. тuberculosis, S. Epidermidis, S. Saprophyticus, Streptococcus pneumoniae, Micrococcus pneumoniae та ін.). Оскільки пилові частинки мають електростатичний заряд, вони є ядрами конденсації, які поглинають вологу та конденсують мікроорганізми, створюючи таким чином відповідні умови для тривалого існування патогенних мікроорганізмів у навколишньому середовищі $[1,2]$.
Особливо небезпечними для людини є частинки розміром менше 1мкм, тому що вони здатні проникати у різні ділянки органів дихання і контамінувати їх патогенними мікроорганізмами [3, 4]. Однак сьогодні відсутні методи досліджень, які дозволяють встановити в кожному конкретному випадку дисперсний склад та вагові концентрації пилу седиментованого на окремих ділянках органів дихання. Також немає відповідних методів встановлення ступеня контамінації цих ділянок мікроорганізмами.

Крім того, відомо, що самі пилові частинки, залежно від своїх фізико-хімічних властивостей, здатні викликати ряд захворювань дихальної системи. Все це є серй- 
озною підставою для розробки та створення приладів для вивчення впливу на органи дихання аерозолів.

Сьогодні існує ряд приладів та методик, за допомогою яких можна оцінити концентрацію та дисперсний склад аерозолів, вміст в них мікроорганізмів, визначити дозу, поглинуту органами дихання [5, 6, 7]. Однак жоден із них не дозволяє встановити, на яких ділянках дихальних шляхів седиментуються пилові частинки різної маси та розмірів.

Предметом дослідження - були аерозолі різні за своїм дисперсним складом та масою.

Мета дослідження розробити пристрій, який дозволить визначити дисперсний склад та поглинуту дозу аерозолю окремими ділянками органів дихання.

\section{Основна частина.}

Нами було поставлено завдання розробити пристрій для дослідження здатності осідання пилових части- нок різних розмірів та мікроорганізмів у різних відділах органів дихання.

В основу будови пристрою було поставлено завдання забезпечити можливість визначення сорбційної здатності різних відділів органів дихання.

Результати досліджень та їх обговорення.

Основна ідея розробленого нами пристрою для визначення величини поглинутої дози пилу полягає у тому, що працюючи у різних режимах, він здатний затримувати та накопичувати на спеціальних фільтрах пил, який вдихається, та пил, який видихається з окремих ділянок органів дихання. На основі отриманих результатів кількість пилу, що осів в окремих ділянках, розраховується за відповідною формулою.

Прилад має наступну будову (рис.1): 1 - еластична маска, яка натягається на обличчя; 2 - блок затримки вдихуваного аерозолю з краном 2.1 перероз-

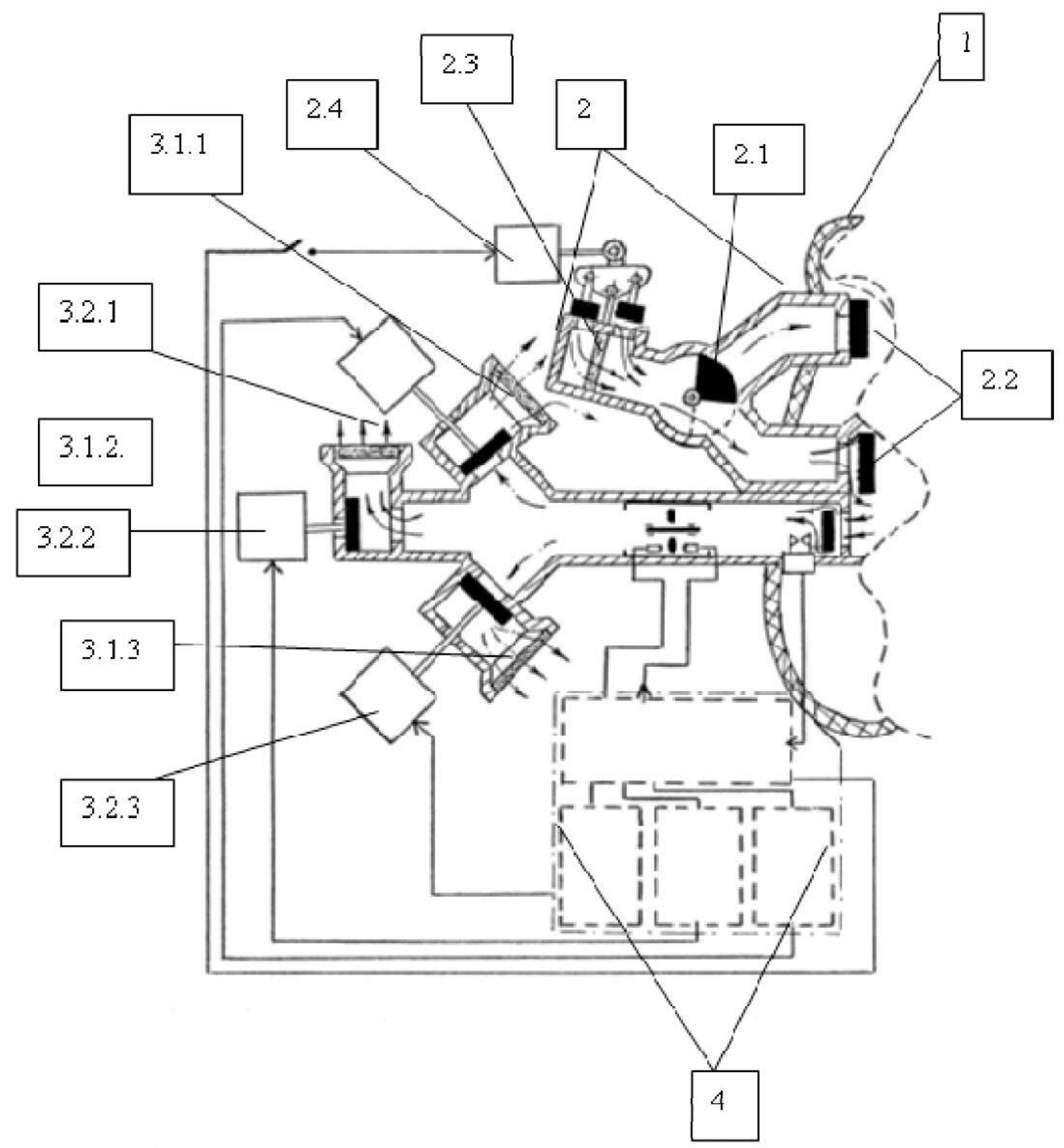

Puc. 1. Пристрій для визначення величини поглинутої і видихуваної дози пилу. 
поділу повітряних потоків при диханні ротом або носом, клапанів вдиху 2.2, фільтра 2.3, та механізму подачі повітря через фільтр або поза фільтром 2.4; 3 - блок затримки видихуваного аерозолю 3 окремих ділянок органів дихання, оснащений фільтрами 3.1.1, 3.1.2, 3.1.3 та механізмами скерування повітряних потоків на відповідні фільтри 3.2.1, 3.2.2, 3.2.3; 4 блок керування введення та отримання інформації по об'ємах повітряних потоків.

Прилад працює у двох режимах.

У першому режимі при вдиху повітря поступає через фільтр 2.3, де мікроорганізми і пил осідають. Вдих повітря може відбуватися або носом, або ротом, що регулюється краном.

У другому режимі перед роботою у прилад вводиться інформація про об'єми окремих відділів органів дихання (у нашому випадку носоглотки, трахеї, легенів). При вдиханні повітря проходить поза фільтром через рот або ніс. При видиху повітря поступово виходить з органів дихання і проходить через три різних фільтри 3.1.1, 3.1.2, 3.13, що відповідають трьом окремим відділам дихальної системи (носоглотки, трахеї, легенів). На трьох фільтрах затримуються час-

\section{Лiтература}

1. Деклараційний пат. 47675 А УЬраїна, МКИ С01М5/00. Спосіб визначення фізичних параметрів мікрочастинок середовища / Кашуба М. О., Бойчук Б. Р. (Україна); ТДМА №2001075017 ; заявл. 17.07.2001 ; опубл. 15.07.2002, Бюл. № 7- 4 с.

2. Деклараційний патент на винахід 47675 А Україна, МПК СЮ 1 N15/00. Спосіб визначення фізичних параметрів мікрочастинок середовища / М. О. Кашуба, Б. Р. Бойчук. - № 2001075017 ; заявл. 17.07.2001 ; опубл. 15.07.2002, Бюл. № 7. 3. Деклараційний патент на винахід 68094 А Україна, МПК СЮ 1 N15/00. Спосіб визначення фізичних параметрів мікрочастинок газопилового середовища / О. М. Кашуба, К. О. Пашко, М. О. Кашуба. - № 2003108889 ; заявл. 01.10.2003 ; опубл. 15.07.2004, Бюл. № 7 тинки пилу та мікроорганізми, які людина видихає із трьох відділів дихальної системи. Досліджуючи ці фільтри за допомогою різних методик, можна встановити характер видихуваного пилу, тобто його масу, концентрацію, дисперсний склад частинок.

Концентрація пилу, що залишилась у трьох частинах дихальної системи, обчислюється за формулами:

$\mathrm{CS} 1=(\mathrm{C} 0 / \mathrm{V} 0-\mathrm{C} 1 / \mathrm{V} 1)^{*} \mathrm{V0}$ (для носоглотки);

$\mathrm{CS} 2=(\mathrm{C} 1 / \mathrm{V} 1-\mathrm{C} 2 / \mathrm{V} 2)^{*}(\mathrm{~V} 0-\mathrm{V} 1)$ (для бронхів);

$\mathrm{CS} 3=(\mathrm{C} 2 / \mathrm{V} 2-\mathrm{C} 3 / \mathrm{V} 3)^{*}(\mathrm{~V} 0-\mathrm{V} 1-\mathrm{V} 2)$ (для легенів);

де C (0-3) - концентрація частинок, що осіли на фільтрах;

V (0-3) - об'єми повітря, що пройшли через фільтр

$\mathrm{S}(1-3)$ - концентрація частинок, що осіли в органах.

Щодо кількості мікроорганізмів, то їхні обчислення проводяться за кількістю колоній, які висіваються 3 пилу, що осів на вдихувальному фільтрі і на видихувальних.

Висновок. Запропонований прилад забезпечує високий рівень функціональної ефективності, дає можливість визначити поглинуту дозу аерозолю окремими ділянками органів дихання, а також його дисперсний склад.

4. Патент Ш 2381003 (51) МПК 2008149599/12, 17.12.2008 Способ очистки от пыли и мусора с использованием ультразвука / Бахарев Сергей Алексеевич

5. Патент России №2 2096758. Способ определения количества субмикронных частиц в газах. МПК7 СЮШ15/02. Опубликовано: 1997.11.20

6. Патент России № 2147739. Устройство контроля запыленности воздуха. МПК7 С0Ш15/02. Опубликовано: 2000.04.20

7. Патент России №2 2200314. Способ определения статистического распределения частиц по размерам. МПК7 С01M5/02. Опубликовано: 2001.06.22 